\title{
Smart inzulin: az előállítás technikája és az első (experimentális) eredmények
}

\author{
Gerő László dr.
}

\begin{abstract}
Összefoglalás
A közelmúltban amerikai kutatók egy olyan glukózreszponziv inzulinadagoló rendszert („smart insulin” kezelés) fejlesztettek ki, amely képes utánozni az egészséges ember béta-sejtjeinek müködését. Hialuronsavból és 2-nitro-imidazolból olyan mikroszkópos, hipoxiaszenzitiv falú hólyagcsákat képeztek (átmérö 118 nanométer), amelyekbe még humán rekombináns inzulint és glukózoxidáz enzimet juttattak. A hólyagcsákat apró túkbe vitték be (hosszméret 600 mikron, alsó pórus átméröje 10 mikron), és a hólyagcsákkal feltöltött tü-sorozatot egy orvosi tapaszhoz erösítették. Amikor a tapaszt a börre erösitették, a tük vége a subcutan zsírszövetbe ért. A környezet glukózkoncentrációjának emelkedése a vezikulákban a glukózoxidáz aktiválását, és igy az oxigén felhasználását és következményes hipoxiát okozott. A hipoxia a hólyagcsák falának feloldódását és az inzulin kiáramlását váltotta ki. Minél magasabb a glukózkoncentráció, annál nagyobb mértékü az inzulinkiáramlás. A leírt rendszer tehát a glukózkoncentráció emelkedésével arányos inzulinválaszt provokál. Amennyiben ezt humán vizsgálatokban is bizonyitani lehet, akkor ez a módszer alkalmas lehet a diabeteses betegekben a glukózreszponziv inzulinszekréció visszaállítására.
\end{abstract}

\section{- Kulcsszavak: smart insulin, glukózoxidáz, glukózreszponziv inzulinszekréció}

\section{Smart insulin: development of the system and the first (experimental) results}

Summary: A glucose-responsive insulin delivery system ("smart insulin" treatment) has been recently developed by American researchers that can mimick the function of healthy human beta-cells. Glucose-responsive vesicles were let to be self-assembled from hypoxia-sensitive hyaluronic acid conjugated with 2-nitro-imidazole. These vesicles (with a diameter of 118 nanometer) were loaded with human recombinant insulin and glucose oxidase. The vesicles were packed into microneedles which were attached to a medical patch. The length of the microneedles were $600 \mathrm{~mm}$ and the diameter of the tip was $10 \mathrm{~mm}$. When this patch was applied to the skin the needles arrived at the subcutanous fatty tissue. Elevation of glucose concentration in the surrounding tissues activated the glucose oxidase enzyme in the vesicles and led to enhanced consumption of oxygen. The consequent hypoxia resulted in a dissolution of the vesicle wall and insulin release from the vesicles. Higher glucose concentration induced greater insulin release. Thus, the magnitude of insulin output was in correlation with the elevation of glucose level. If this system would also work in diabetic patients then glucose-responsive insulin secretion could be restored in patients suffering from diabetes mellitus.

Key words: smart insulin, glucose oxidase, glucose-responsive insulin secretion

Rövidítések

GO : glukózoxidáz (glucose oxidase); GRV: glukózreszponzív vezikula (glucose reponsive vesicle); HA: hialuronsav (hyaluronic acid); HS-HA: hipoxiaszenzitiv hialuronsav (hypoxia-sensitive hyaluronic acid); $\mathbf{H}_{2} \mathbf{O}_{2}$ : hidrogén-peroxid (hydrogen peroxide); 2-NI: 2-nitro-imidazol; 2-AN: 2-amino-imidazol; PBS: foszfátpuffer (phosphate buffered saline) 
$\mathrm{E}$ gészséges személyeken az éhomi vércukorszint szűk határok, 4,0-5,5 mmol/1 között ingadozik, és - átmeneti emelkedést követően - étkezés után is rövid időn belül visszatér a fenti tartományba. Szervezetünkben a cukorszint alakulását komplex hormonális folyamat szabályozza, ami egyrészt a vércukorcsökkentő inzulin, másrészt a cukorszintet emelő hormonok (adrenalin, glukagon, kortizol, növekedési hormon stb.) időben és hatáserősségben jól összehangolt aktivitásának az eredménye.

Amikor az endogén inzulinelválasztás abszolút vagy relatív értelemben elégtelenné válik, exogén inzulin bevitelére van szükség. Ezzel azonban az ún. minute-to-minute szabályozás, azaz a vércukorszint emelkedésére szinte azonnal fokozódó inzulinszekréció nem utánozható. Az inzulinanalógokkal jobban megközelíthető a fiziológiás inzulinelválasztás, mint a tradicionális humán inzulinokkal, de a fiziológiás „fine-tuning” nem érhető el. Gyakorlatilag az inzulin beadása után a „tapasztalat” szerint étkezünk, és így próbáljuk a vércukorszint csökkenését vagy túlzott emelkedését kivédeni. A hyperglykaemiás periódusok és hypoglykaeiás epizódok kialakulása azonban elkerülhetetlen.

A tökéletes normoglykaemia csak „visszacsatolásos" rendszerrel lenne elérhető. Ún. closed-loop rendszerű, az inzulint az aktuálisan mért vércukorszint szerint adagoló pumpák ugyan már megjelentek a piacon, de ezek a készülékek rendkívül drágák, a hozzáférés nehéz és tömeges elterjedésükre egyelőre nem lehet számítani. A sikeres sebészi pancreastranszplantáció ugyan hosszú

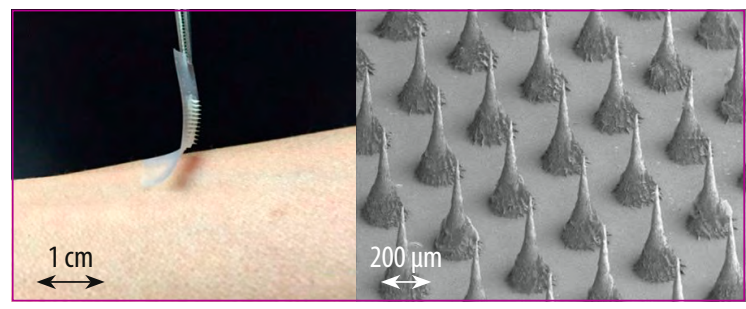

1. ábra. Az orvosi tapasz a tükkel a börre helyezés elött (balra), illetve a tapaszon lévő tüsor részlete ki-

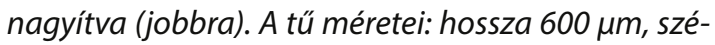
lessége a tapasznál 150 um, a hegyénél $10 \mu \mathrm{m}$ (Yu J et al. ${ }^{2}$ alapján, módosítva) évekre tökéletes szénhidrát-anyagcserét biztosít inzulinkezelés nélkül is, de ez a beavatkozás a beteget jelentősen megterheli, s emiatt csak kisszámú, szelektált csoporton alkalmazható. További korlátozást jelent a donorhiány, valamint az a tény, hogy a szervátültetés után tartós immunoszuppresszív terápiára van szükség - annak minden káros következményével. A Langerhans-szigetek transzplantációja kisebb beavatkozás, de a beültetett szigetek túlélése viszonylag rövid, és a beavatkozás szintén immunszuppresszív kezeléssel jár. Mesterséges béta-sejtek kifejlesztése őssejtekből, pluripotens sejtekből egyelőre experimentális stádiumban van. ${ }^{1}$

\section{A „smart inzulin” kezelés elvi háttere}

A közelmúltban egyesült államokbeli kutatók egy új módszert dolgoztak ki, amelynek segítségével a vércukorszint aktuális ingadozásait követő inzulinmennyiség juttatható a szervezetbe. A terápia kivitelezéséhez a bőrfelületre olyan „tapaszt” helyeznek, amelynek alsó (a bőr felé néző) felszínén a bőrön áthatoló apró tûk helyezkednek el. A tük végében van a speciális, mikroszkopikus nagyságú hólyagocskákba helyezett inzulin. A környezet cukorszintjének emelkedésekor az emelkedés nagyságával arányos mennyiségủ inzulin kerül át a tűkből a subcutan zsírszövetbe. A reakció kifejezetten gyors, a szervezetbe jutó inzulin így képes szabályozni az étkezést (vagy a cukorterhelést) követő vércukorszint-emelkedést.

\section{Az inzulint tartalmazó glukózreszponzív rendszer kialakítása}

Az inzulinadagoló rendszer fontos eleme egy olyan, a bőrfelületre helyezhető tapasz, amelynek alsó (a bőrfelület felé néző) oldalán apró, szuperhegyes „tűk” állnak ki. A tapasz bőrre helyezésekor a tűk áthatolnak a bőrön, és hegyük a bőr alatti zsírszövetbe ér. A megfigyelések (a betegek visszajelzése) szerint a tapasz felhelyezése fájdalmatlan.

A tűk átmérője a hegyes végén (tehát a subcutan szövetben) mindössze $10 \mu \mathrm{m}$, felfelé (a tapasz felé) azonban a tủ tölcsérszerűen kiszélesedik, itt 
az átmérő $150 \mu \mathrm{m}$, a tű hossza mintegy $600 \mu \mathrm{m}$ (1. ábra). A tűk falának anyaga egy szilikon öntőformában kialakított, metilén-bisz-akrilamiddal kezelt („keményített”) hialuronsav váz. A fal szilárdságát és stabilitását még UV-besugárzással (keresztkötések kialakításával) is fokozzák. A tűket egy orvosi tapasz alsó (a bőr felé néző) felületéhez erősítik, ahol $6 \times 6 \mathrm{~mm}$-es felületre $11 \times 11$ darab tű jut. A vizsgálatok szerint a tűk hegye és fala megfelelően stabil volt a bőr penetrációjához.

Minden egyes tűbe beviszik a hialuronsav-2-nitro-imidazol falú hólyagcsákat, amelyekben humán rekombináns inzulin és glukózoxidáz enzim van vizes oldatban. Centrifugálással a hólyagcsákat a tű hegyébe juttatják. A tủ végébe került, inzulintartalmú hólyagocskák átmérője 118 nanométer. A 2-nitro-imidazol fal erősen hidrofób - ezért képes szilárd falat képezni a vizes oldatban lévő „inzulin + glukózoxidáz" körül. Ugyanakkor a 2-nitro-imidazol erősen hipoxiaszenzitív is. Előzetes in vitro vizsgálatokban a hólyagcsák $4{ }^{\circ} \mathrm{C}$-on tartva 1 hónapon át stabilnak bizonyultak.

Amikor a környezet glukózkoncentrációja emelkedik, és a glukóz a tủ hegyén át a tűbe jutva érintkezésbe jut a hólyagcsákkal, akkor a glukózoxidáz enzim aktiválódik, és oxidálja a glukózt: oxigén és víz felvételével glukonsav és $\mathrm{H}_{2} \mathrm{O}_{2}$ keletkezik az alábbi képlet szerint:

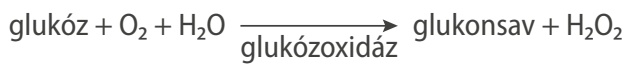

Az oxigén felhasználása miatt hipoxia alakul ki a hólyagcsákban, s ennek hatására a hólyagcsa fa- lában lévő 2-nitro-imidazol átalakul 2-amino-imidazollá, és ezzel az addig hidrofób tulajdonságú fal hidrofillé válik, stabilitása a vizes közegben megszűnik, a hólyagcsa fala disszociál. A hólyagcsa így szétesik, és a benne lévő inzulin kiáramlik a szövetekbe (2. ábra).

\section{A GRV müködése in vitro}

Az inzulin szekréciójának vizsgálatára a leírt módon előállított, inzulinnal kitöltött hólyagcsákat glukózmentes foszfátpufferban, illetve $5,5 \mathrm{mmol} / 1$ és $22,2 \mathrm{mmol} / \mathrm{l}(100 \mathrm{mg} / \mathrm{dl}$ és $400 \mathrm{mg} / \mathrm{dl})$ glukózkoncentrációjú oldatban inkubálták. Az inkubálófolyadék inzulinkoncentrációját eleinte óránként, később ritkábban mérték, összesen 24 órán át. A foszfátpuffer alig váltott ki inzulinkiáramlást, az 5,5 mmol-os oldat mellett (azaz a kb. „normálisnak" tekinthető glukózszint mellett) ennél határozottan magasabb inzulinszinteket nyertek. A 22,2 mmol-os (tehát kifejezetten magas) glukózkoncentráció jelentősen tovább emelte a mért inzulinértékeket (gyakorlatilag minden mért időpontban szignifikánsan magasabb volt a kumulatív inzulinkoncentráció $[\mathrm{p}<0,05])$. A hólyagcsák tehát glukózdependens módon és mennyiségben engedik kiáramlani az inzulint (ezért az elnevezés: glukózreszponzív vezikula, GRV).

Az inzulinszekréciót nem befolyásolta a $\mathrm{pH}$, de kifejezetten befolyásolta mind a glukózkoncentráció, mind a GRV-be bevitt glukózoxidáz mennyi-

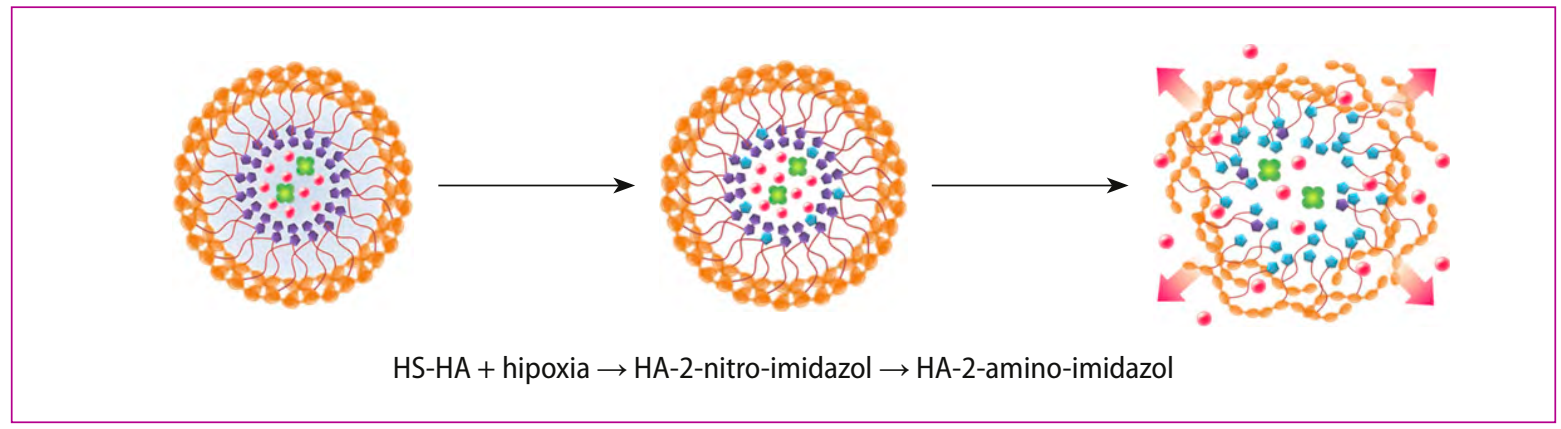

2. ábra. Glukózreszponzív hólyagcsák keresztmetszeti képe. Bal oldalon: ép hólyagcsa, hidrofób fallal (sárga: hilauronsav, sötétkék: 2-nitro-imidazol, piros: inzulin, zöld: glukózoxidáz); középen: a hólyagcsa átalakulása a hipoxia hatására: megjelenik a 2-amino-imidazol (világoskékkel jelölve); jobb oldalon: a hipoxia hatására a hólyagcsa fala disszociál és az inzulin kiáramlik a hólyagcsából a környezetbe (Yu J et al.² alapján, módosítva) 
sége. A szerzők megvizsgálták, hogy a GRV működését mennyiben módosítja, ha a $\mathrm{GO}_{\mathrm{x}}$-nek csak a fél adagját viszik be a hólyagcsákba, s azt találták, hogy az elválasztott inzulin így szignifikánsan kevesebb volt. Az elválasztott inzulin mennyisége tehát a hólyagcsákba vitt $\mathrm{GO}_{\mathrm{x}}$ mennyiségével is módosítható.

\section{A GRV müködése in vivo körülmények között (experimentális adatok)}

A GRV működését tanulmányozták kísérleti állatokban is. Egerekben kis dózisú streptozotocin ismételt adásával az 1-es típusú diabetesnek megfelelő cukorbetegséget idéztek elő, majd az állatok borotvált hátára GRV-tapaszt helyeztek fel. A „tűk” helyzetét utólag (az állatok leölése után történt boncolás során) ellenőrizték, azok minden esetben a bőr alatti zsírszövetbe értek. A GRV-k egy részét teljes, másik csoportját fél adag glukózoxidáz enzimmel töltötték fel, és voltak csak inzulint tartalmazó (enzim nélküli) GRV-k is.

A diabeteses állatok kiindulási vércukorszintje átlagosan 33,3 mmol/1 volt. A tapasz felhelyezése után ez a szint szignifikáns mértékben csökkent $(\mathrm{p}<0,05)$, átlagosan 10,0 mmol/l körüli értékre. Ez a jelentős mértékű előnyös változás (több mint 20,0 mmol/1 nagyságrendű cukorszintcsökkenés) azokra az esetekre vonatkozott, ahol 1 egységnyi $\mathrm{GO}_{\mathrm{x}}$-t tartalmaztak a hólyagcsák. Ezután lassan, fokozatosan újra emelkedett a vércukorszint, de csak kb. 10 óra múlva érte el a kiindulási szintet. Fél egységnyi $\mathrm{GO}_{\mathrm{x}}$ szignifikánsan kisebb mértékben csökkentette a vércukorszintet, mint az 1 egységnyi $\mathrm{GO}_{\mathrm{x}}$-tartalmú hólyagcsák. Az enzim nélküli, csak inzulint tartalmazó hólyagcsák bevitele nem befolyásolta a vércukorszintet.

$\mathrm{Az}$ inzulingörbék a fentieknek megfelelően alakultak: az egységnyi $\mathrm{GO}_{\mathrm{x}}$ bevitele után az inzulinszint meredeken emelkedett, egészen kb. 1100 $\mu \mathrm{E} / \mathrm{ml}$ szintig(!), majd lassan csökkent, de még 10 óra elteltével is a kiindulási szint felett volt. A fél egységnyi enzimet kapók csoportjában szignifikánsan kisebb mértékű volt az inzulinszint emelkedése, maximum kb. $400 \mu \mathrm{E} / \mathrm{ml}$.

Egy másik kísérletsorozatban az állatok egy részén 1 órával a tapasz felhelyezése után intraperitoneális glukózterhelést végeztek. Azokon a dia- beteses állatokon, amelyek 1 egységnyi $\mathrm{GO}_{\mathrm{x}}$-et kaptak, a cukorterhelés csak enyhe cukorszintemelkedést váltott ki, viszonylag gyors (az ip. glukózinjekció beadása után már kb. 30 perccel induló) vércukorszint-csökkenéssel - a görbe lefutása hasonlított az egészséges állatokon végzett ip. glukózterhelés vércukorgörbéjéhez.

Egy harmadik kísérletsorozatban azt is vizsgálták, hogy a diabeteses egereken a GRV ismételt beültetése képes-e tartósan stabilizálni az állatok vércukorszintjét. Az 1 egységnyi $\mathrm{GO}_{\mathrm{x}}$-töltetű vezikulákkal (inzulin $5 \mathrm{mg} / \mathrm{tskg}$ ) kezelt diabeteses állatok vércukorszintje 11,0 mmol körüli értékre csökkent, és ez a szint kb. 3 órán át stabilnak bizonyult. Egy második tapasz felhelyezése tovább hosszabbította ezt az állapotot, de nem okozott hypoglykaemiát. Ezzel szemben azonos mennyiségü $(5 \mathrm{mg} / \mathrm{tskg})$ inzulin ismételt adása hypoglykaemiához vezetett.

\section{Biokompatibilitási vizsgálatok}

A GRV fala nagyrészt hialuronsavból áll. A szervezetben a hialuronsav több szövetben is előfordul, tehát a HA nem szövetidegen anyag. A GRV anyagát számos toxicitási vizsgálatnak vetették alá, és a különböző koncentrációk semmiféle toxikus reakciót nem váltottak ki.

A GRV (és a benne lévő inzulin + glukózoxidáz) a tapasz felhelyezését követően nem okozott a környezetben gyulladást, nem váltott ki semmiféle immunológiai vagy egyéb adverz reakciót. ${ }^{2}$

\section{A módszer (potenciális) előnyei}

Az inzulinkiáramlás mennyisége és sebessége ebben a hipoxia vezérelte rendszerben felülmúlta a hasonló glukózszenzitív rendszereket, amelyek pl. a pH változásával próbálták felszabadítani a lekötött inzulint. Ez különösen vonatkozik az in vivo körülményekre, ahol a $\mathrm{pH}$ változását szinte azonnal pufferolja az élő környezet. Az inzulin koncentrációjának gyors adaptív változása nem csak azt biztosítja, hogy a postprandialis cukorszint-emelkedés ne legyen eltúlzott, hanem egyúttal a hypoglykaemia veszélyét is minimálisra csökkenti. 
Egy másik előny, hogy az inzulin felszabadulásának kinetikáját befolyásolni lehet a $\mathrm{GO}_{\mathrm{x}}$ enzim mennyiségének változtatásával. További előnyt jelent, hogy mind a „tű”, mind a vezikulák falának anyaga hialuronsav-alapú, amely kifejezetten biokompatibilis anyag. A kezelési rendszer kifejlesztése korunk nanotechnikájának egyik gyönyörű példája. ${ }^{3,4}$

A szerzők a potenciális előnyök közül kiemelik még, hogy mind a hypo-, mind a hyperglykaemia gyakorisága jelentősen csökkenhet (a súlyos hypoglykaemia előfordulásának valószínűsége gyakorlatilag nulla), s ennek következtében a glukózvariabilitás szintén minimalizálódik, és a vércukorszint monitorozása szükségtelenné válhat. A glukózszint gyakori napszakos önellenőrzését felválthatja a napi 1-2-szeri vércukorszint-meghatározás. Mindez elsősorban az 1-es típusú diabeteses, de inzulinnal kezelt 2-es típusú cukorbetegek terápiájában is óriási előnyt jelentene mind a szénhidrát-anyagcsere stabilizálása, mind a napi életvitel szempontjából.

A felsorolt előnyök természetesen még csak az experimentális eredmények alapján feltételezettek, megerősítésükhöz klinikai vizsgálatok pozitív eredményei szükségesek.
Irodalom

1. Gerō L: Langerhans-sziget transzplantáció, mesterséges ß-sejt-transzplantáció 1-es típusú diabéteszben. Magyar Tudomány 2015; 176: 864-875.

2. Yu J, Zhang Y, Ye Y, DiSanto R, Sun W, Ranson D, et al.: Microneedlearray patches loaded with hypoxia-sensitive vesicles provide fast glucoseresponsive insulin delivery. Proc Natl Acad Sci 2015; 112: 8260-8265. doi:10.1073/pnas. 1505405112

3. Weiseh 0, Langer R: Diabetes: a smart insulin patch. Nature 2015; 524:39-40. doi:10.1038/524039a

4. Welseh 0 , Tang $B C$, Whitehead $K A$, Anderson $D G$, Langer R: Managing diabetes with nanomedicine: challenges and opportunities. Nature Rev Drug Discov 2015; 14: 45-54. doi:10.1038/nrd4477

Közlésre érkezett: 2017. május 8.

Közlésre elfogadva: 2017. május 18.

\section{A szerzö levelezési címe}

Dr. Gerő László

Semmelweis Egyetem, ÁOK, I. sz. Belklinika

1083 Budapest, Korányi S. u. 2/a

E-mail: gero@bel1.sote.hu 